\title{
Sizing Large Proteins and Protein Complexes by Electrospray Ionization Mass Spectrometry and Ion Mobility
}

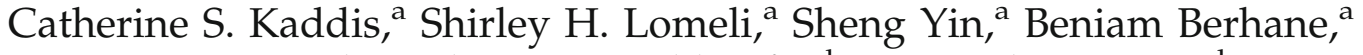 \\ Marcin I. Apostol, ${ }^{\text {a }}$ Valerie A. Kickhoefer, ${ }^{\mathrm{b}}$ Leonard H. Rome, ${ }^{\mathrm{b}}$ \\ and Joseph A. Loo ${ }^{\mathrm{a}, \mathrm{b}}$ \\ ${ }^{a}$ Department of Chemistry and Biochemistry, and \\ ${ }^{b}$ Department of Biological Chemistry, David Geffen School of Medicine, University of California \\ Los Angeles, Los Angeles, California, USA
}

\begin{abstract}
Mass spectrometry (MS) and ion mobility with electrospray ionization (ESI) have the capability to measure and detect large noncovalent protein-ligand and protein-protein complexes. Using an ion mobility method of gas-phase electrophoretic mobility molecular analysis (GEMMA), protein particles representing a range of sizes can be separated by their electrophoretic mobility in air. Highly charged particles produced from a protein complex solution using electrospray can be manipulated to produce singly charged ions, which can be separated and quantified by their electrophoretic mobility. Results from ESI-GEMMA analysis from our laboratory and others were compared with other experimental and theoretically determined parameters, such as molecular mass and cryoelectron microscopy and X-ray crystal structure dimensions. There is a strong correlation between the electrophoretic mobility diameter determined from GEMMA analysis and the molecular mass for protein complexes up to $12 \mathrm{MDa}$, including the $93 \mathrm{kDa}$ enolase dimer, the $480 \mathrm{kDa}$ ferritin 24-mer complex, the 4.6 MDa cowpea chlorotic mottle virus (CCMV), and the 9 MDa MVP-vault assembly. ESIGEMMA is used to differentiate a number of similarly sized vault complexes that are composed of different N-terminal protein tags on the MVP subunit. The average effective density of the proteins and protein complexes studied was $0.6 \mathrm{~g} / \mathrm{cm}^{3}$. Moreover, there is evidence that proteins and protein complexes collapse or become more compact in the gas phase in the absence of water. (J Am Soc Mass Spectrom 2007, 18, 1206-1216) (c) 2007 American Society for Mass Spectrometry
\end{abstract}


urrent research using electrospray ionization (ESI) coupled to mass spectrometry (MS) and ion mobility spectrometry (IMS) has demonstrated the ability of these inherently gas-phase techniques to provide details about the structures of large macromolecules [1-4]. Protein function determination is critical for the identification of potential drug targets, an understanding of diseases, and for the elucidation of biochemical pathways; structural studies aid in this assessment of protein function [1, 3, 5]. However, high-resolution structural analysis techniques such as NMR and X-ray crystallography are limited by the size of the protein and its purity and large sample quantity requirements; advantages of mass spectrometry and ion mobility include high sensitivity and low sample con-

This paper is submitted to honor Professor David E. Clemmer for his well-deserved receipt of the 2006 ASMS Biemann Medal.

Address reprint requests to Dr. J. A. Loo, Department of Chemistry and Biochemistry, David Geffen School of Medicine, University of CaliforniaLos Angeles, Los Angeles, CA 90095-1570, USA. E-mail: JLoo@chem. ucla.edu sumption [6]. As soft ionization techniques, electrospray ionization (ESI) along with matrix-assisted laser desorption ionization (MALDI) revolutionized protein mass spectrometry. Moreover, ESI-MS and ESI-IMS can be used to observe intact, weakly bound noncovalent protein complexes. Data from these studies have been used to measure the stoichiometry of binding partners in biological complexes [6, 7].

MS and IMS are complementary methods, as both provide information on the relative molecular mass of large proteins [8-10]. However, for very large proteins or protein complexes and for mixtures, the multiply charged molecules produced from the ESI process can lead to difficulties in the interpretation of MS/IMS spectra. To overcome this limitation, charge reduction to singly charged molecules can simplify the spectra obtained by ESI-MS/IMS for large macromolecules [8-12]. The utility of charge reduction for the study of supramolecular complexes has been demonstrated through the use of ESI-GEMMA (gas-phase electrophoretic mobility molecular analyzer) for such applica- 
tions $[3,7,8,13]$. Within the electrospray unit of the GEMMA apparatus, the protein solution is sprayed into a mist of highly charged droplets, which are then charge-reduced by a bipolar neutralizer. Most of the particles are reduced to neutral charge, but a fraction of the particles possess a single charge. A differential mobility analyzer (DMA) separates the particles based on their electrophoretic mobility in air. Charged particles are detected by a condensation particle counter. The resulting GEMMA spectrum shows the concentration of charged particles as a function of their calculated electrophoretic mobility diameters (EMD) [8-11].

A distinguishing feature of ESI-IMS (GEMMA) from ESI-MS is the capability to provide molecular "size" information [13]. Although both methods allow the relative molecular mass to be derived, GEMMA does so through its measurement of EMD [8, 10]. ESI-GEMMA studies of primarily globular proteins have shown a correlation between electrophoretic diameter and relative molecular mass for proteins and protein complexes ranging from $3 \mathrm{kDa}$ to $2 \mathrm{MDa}$ and measuring 2.6 to $21.7 \mathrm{~nm}$ in EMD [8]. Highlighting the role of water in supramolecular complexes and the potential of ESIGEMMA as a structural elucidation tool, Thomas et al. showed that the measured electrophoretic mobility for selected viruses were within $15 \%$ of the diameters measured by X-ray crystallographic studies [13]. Furthermore, studies using other ESI-IMS techniques have shown agreement between X-ray crystal structure and gas-phase structure dimensions for both globular proteins and large protein complexes. The Robinson laboratory has demonstrated that the TRAP protein complex measured by an ion mobility/mass spectrometry hybrid instrument was consistent with X-ray crystal structure determined dimensions [4]. Clemmer and coworkers have shown that the lower ESI-generated charged state ions of ubiquitin were also consistent with X-ray crystal structure determined dimensions [14]. This agreement between IMS determined and X-ray crystal structure determined dimensions was also observed for cytochrome $c$ and BPTI by Jarrold and coworkers [15].

We are interested in exploiting the potential for using ESI-GEMMA to provide information on not only the general size dimensions of proteins, but also the protein molecule's physical transition from the solution phase to the gas phase. Important to the interpretation and analysis of ESI-MS and ESI-IMS data is the identification of the structural features of the gas-phase proteins and protein complexes that reflect their solution-phase counterparts. As a result of solvent evaporation and removal from the protein's solvation sphere and its interior core, is there an accompanying change in the relative structure of the protein? Do protein structures collapse upon transitioning to the gas phase, and is this collapse measurable by GEMMA methods?

To address these questions, we present the results of our ESI-GEMMA analyses for a variety of proteins in the context of crystal and solution structure predicted dimensions. One of the proteins that is featured is the vault, the largest known ribonucleoprotein cellular particle of $\sim 13 \mathrm{MDa}$ in mass [16-18]. The native vault complex is composed of a short sequence of untranslated RNA and three different protein components: 97 kDa MVP (major vault protein), 240 kDa TEP1, and 193 kDa VPARP [16, 18]. These hollow, ellipsoidal complexes are proposed to be involved in nuclear cytoplasmic transport [18], and they have been implicated in multidrug resistance and as a prognostic marker for cancer chemotherapy failure [18, 19]. However, the precise function of these ribonucleoprotein complexes remains unknown. Recently published experiments using ESI-GEMMA contributed to the determination that vaults could incorporate other proteins into their interior after formation of an MVP-only outer shell [20]. Further research on the relationship between the gasphase and solution-phase structures of proteins and protein complexes will aid in our ongoing research on vault structure and function. Given their multi-MDa size, nonspherical shape, and hollow nature, vaults have been measured to examine specific characteristics of gas-phase macromolecular structures and to demonstrate the applicability of the GEMMA method to the study of large protein complexes.

\section{Experimental}

\section{Materials}

Yeast enolase was purchased from Sigma Chemical (St. Louis, MO) and the equine ferritin proteins were obtained from Calbiochem (San Diego, CA). CCMV was provided kindly by Dr. Laurence Lavelle, UCLA Department of Chemistry and Biochemistry. The Archaeoglobus fulgidus ferritin was provided by Dr. Imke Schroeder, UCLA Department of Microbiology, Immunology, and Molecular Genetics. Vaults were prepared as described previously [20].

\section{Gas-Phase Electrophoretic Mobility Molecular Analyzer}

The details of the GEMMA instrumentation and method for measuring protein size have been described elsewhere [8, 10, 11]. The GEMMA instrument (TSI Inc., St. Paul, MN) consists of an ESI unit with a neutralizing chamber, a nano differential mobility analyzer (DMA), and condensation particle counter (CPC). The ESI unit and DMA operate at atmospheric pressure and at room temperature. The CPC operates at atmospheric pressure and at the temperatures described below.

One end of a fused silica capillary tube (polyimide coated, $25 \mathrm{~cm}$ long, $25 \mu \mathrm{m}$ i.d. and $150 \mu \mathrm{m}$ o.d.) is immersed in the sample protein solution. The other end of the capillary is located within the electrospray chamber and displays a tip ground to a conical shape. Liquid is introduced and aspirated through the capillary into the electrospray chamber by reducing the pressure 
in the entire system. Protein solutions are introduced via the ESI source at a flow rate of $70 \mathrm{~nL} / \mathrm{min}$. A thin $\mathrm{Pt}$ electrode is dipped in the protein solution and is connected to the positive side of the electrospray voltage supply. The shape of the emerging droplet was observed visually and controlled by adjusting the electrospray voltage; ESI was operated in the "cone-jet mode". The typical electrospray voltage ranged from 1.5 to $2.5 \mathrm{kV}$ with currents ranging from 200 to $300 \mathrm{nA}$. Air and $\mathrm{CO}_{2}$ surround the spray tip entering the electrospray chamber at 1 to $2 \mathrm{~L} / \mathrm{min}$ and $0.1 \mathrm{~L} / \mathrm{min}$, respectively. Carbon dioxide is used to stabilize the electrospray against corona discharge.

The multiply charged aerosol droplets formed are swept into the neutralizing chamber by air and $\mathrm{CO}_{2}$ flow. The gases present inside the neutralizing chamber are ionized by a ${ }^{210} \mathrm{Po} \alpha$-radiation source $(5 \mathrm{mCi}$, model P-2042 Nucleospot local air ionizer; NRD, Grand Island, NY). Charge reduction occurs from the interaction of the multiply charged particles with ionized primary gas ions. Evaporation and this neutralization process produce predominantly neutral macromolecular particles with a small fraction of the particles possessing a single (or more) positive or negative charge.

Protein particles enter the DMA and are separated by their electrophoretic mobility in air at atmospheric pressure. This occurs in the presence of an applied radial electric field orthogonal to a laminar flow of sheath air. The electric field is created by the potential difference between the central electrode rod connected to a negative power supply and the electrically grounded outer cylindrical electrode. The aerosol from the ESI unit enters the DMA through a slit in the outer electrode. The coaxial flow of filtered sheath air is set at $15-20 \mathrm{~L} / \mathrm{min}$. Negatively charged particles are repelled by the inner electrode, while neutral particles exit the DMA with the excess air. Positively charged particles are carried by the sheath flow and are attracted to the center electrode. Only positively charged particles with the correct trajectory as determined by their electrophoretic mobility exit the center electrode en route to the CPC. A narrow range of electrophoretic mobilities is selected by controlling the voltage difference between the two electrodes. For a given applied voltage to the center collector rod, the mobility of particles is calculated from the geometry of the coaxial chamber and the recirculating flow rate using the algorithm of Knutson and Whitby [21, 22].

Electrical mobility, $Z_{\mathrm{EM}}$, measures a particle's ability to move in an electrical field. Consider a particle with $n$ electric charges that experiences an electrical force, E. The particle will move through the gas in which it is suspended until it quickly reaches its terminal velocity, $v$. The EMD of the particle, its Millikan diameter, $\mathrm{D}_{\mathrm{EM}}$, is defined as the diameter of a singly charged sphere with the same electrophoretic mobility as the particle $[23,24]$,

$$
\mathrm{Z}_{\mathrm{EM}}=\mathrm{neC} / 3 \pi \mu \mathrm{D}_{\mathrm{EM}}
$$

where e is elementary charge, and $\mathrm{C}$ is the Cunningham correction factor. The Cunningham correction factor is always greater than 1 and accounts for molecular slip for particles less than $1 \mu \mathrm{m}$. Molecular slip occurs when the size of the particle approaches the mean free path of the gas and the Stokes drag force is reduced [23]. The equation then used by the software to relate electrophoretic mobility to $\mathrm{D}_{\mathrm{EM}}$ is represented by eq $2[7,23]$.

$$
\begin{aligned}
\mathrm{Z}_{\mathrm{EM}}\left(\mathrm{D}_{\mathrm{EM}}\right)= & \left(\mathrm{e} / 3 \pi \mu \mathrm{D}_{\mathrm{EM}}\right)\left\{1+\left(2 \lambda / \mathrm{D}_{\mathrm{EM}}\right)(1.142\right. \\
& \left.+0.558 \exp \left(-0.999 \mathrm{D}_{\mathrm{EM}} / 2 \lambda\right)\right\}
\end{aligned}
$$

(The gas viscosity, $\mu$, is $1.8203 \times 10^{-5} \mathrm{~kg} / \mathrm{m} / \mathrm{s}$ and the molecular mean free path, $\lambda$, is $66.5 \mathrm{~nm}$ at operating pressure.)

From the DMA, the selected macromolecular particles enter the CPC for detection and counting. The monomobile particles are injected into a flow of saturated $n$-butanol vapor at $37^{\circ} \mathrm{C}$. Cooling to $10^{\circ} \mathrm{C}$ produces a well-defined supersaturation which leads to the $n$-butanol vapor condensing on the particles to form droplets. These droplets are detected and counted individually by light scattering.

The DMA voltage is scanned and data recorded by Aerosol Instrument Manager Software (TSI Inc.). The scanning ${ }^{\circ}$ algorithm ${ }^{\circ}$ of $^{\circ} \mathrm{Wang}^{\circ}$ and $^{\circ} \mathrm{Flagan}{ }^{\circ}[25]^{\circ}$ allows ${ }^{\circ}$ for rapid data collection with the exponential increase of the applied voltage to the DMA center rod. In a typical experiment run, the DMA voltage is scanned for $135 \mathrm{~s}$ (120 s for increasing voltage and $15 \mathrm{~s}$ for the return) to sample the diameter range of 2 to $56 \mathrm{~nm}$. The spectra displayed in the figures are particle counts versus EMD in their "uncorrected form". The software corrects for a small fraction of multiply-charged particles assuming the ${ }^{\circ}$ bipolar ${ }^{\circ}$ charge $^{\circ}$ distribution $^{\circ}$ of $^{\circ} \mathrm{Fuchs}^{\circ}[26]^{\circ}$ as $^{\circ} \mathrm{Calcu}^{\circ}$ lated ${ }^{\circ}$ by $^{\circ}$ Wiedensohler's ${ }^{\circ}$ formula ${ }^{\circ}[27] . .^{\circ}$ This ${ }^{\circ}$ charging probability is used to infer the total particle concentration from the measured charged-particle concentration. In addition, compensations are made for the fall-off in efficiency at the bottom of the size range. The corrected spectrum shows aerosol concentration versus EMD. The EMD listed for each protein or protein complex is the centroid of the corrected peak of interest as calculated by Peak Fit (version 4.12, Systat Software, San Jose, CA). A smoothing algorithm was applied to the spectra shown using Igor Pro (version 4.08, Wave Metrics, Lake Oswego, OR).

\section{ESI-MS}

Electrospray ionization mass spectra were acquired with a QqTOF mass spectrometer (QSTAR Pulsar XL; Applied Biosystems/SCIEX, Concord, ON, Canada). A nanoESI source (Proxeon glass capillaries; Odense, Denmark) operating at low analyte flow conditions (50 $\mathrm{nL} / \mathrm{min}$ ) was used with the QqTOF instrument. A metal sleeve used to restrict pumping in the initial region of 
the Q0-focusing quadrupole was used to allow for improved trapping and transmission of the noncovalent complexes $^{\circ}[3] .^{\circ}$ The $^{\circ}$ protein $^{\circ}$ complexes $^{\circ}$ were $^{\circ}$ dissolved and desalted in $10 \mathrm{mM}$ ammonium acetate, $\mathrm{pH} 7$. Protein solutions ( 1 to $10 \mathrm{pmol} / \mu \mathrm{L}$ ) were prepared in nondenaturing (10 $\mathrm{mM}$ ammonium acetate, $\mathrm{pH}$ 6.8) conditions.

\section{Results and Discussion}

\section{General Correlation Between EMD and Molecular Weight}

The electrophoretic mobility diameter (EMD), the Millikan diameter, is defined as the diameter of a singly charged sphere with the same electrophoretic mobility as $^{\circ}$ the ${ }^{\circ}$ particle $^{\circ}[24] .{ }^{\circ}$ Using $^{\circ} \mathrm{a}^{\circ}$ spherical $^{\circ}$ model $^{\circ}$ for ${ }^{\circ}$ the particles, the volume of this protein particle $\left(\mathrm{V}_{\mathrm{EMD}}\right)$ can be $^{\circ}$ calculated ${ }^{\circ} y^{\circ} \mathrm{eq}^{\circ} 3^{\circ}[7]$.

$$
\mathrm{V}_{\mathrm{EMD}}=(\pi / 6)\left(\mathrm{EMD}^{3}\right)
$$

The effective density of the particles $(\delta)$ can then be calculated as the molecular weight (MW) divided by this calculated volume, $\mathrm{V}_{\mathrm{EMD}}$, and ${ }^{\circ}$ Avogadro's number, $\mathrm{N}_{\mathrm{o}}$ [7]. (Unlike MW, the values of EMD and $\mathrm{V}_{\mathrm{EMD}}$ are based on individual particles rather than a molar quantity.)

$$
\delta=\mathrm{MW} /\left(\mathrm{N}_{\mathrm{o}}\right)\left(\mathrm{V}_{\mathrm{EMD}}\right)=\mathrm{MW} /\left(\mathrm{N}_{\mathrm{o}}\right)(\pi / 6)\left(\mathrm{EMD}^{3}\right)
$$

Figure $^{\circ}{ }^{\circ}$ shows $^{\circ} \mathrm{a}^{\circ}$ plot $^{\circ}$ of ${ }^{\circ}$ the $\mathrm{MW}^{\circ}$ versus ${ }^{\circ}$ electrophoretic mobility diameters $\left(\mathrm{D}_{\mathrm{EM}}\right)$ for a range of macromolecules measured ${ }^{\circ}$ by $^{\circ}$ ESI-GEMMA $^{\circ}$ by $^{\circ}$ the $^{\circ}$ Allmaier ${ }^{\circ}$ group $^{\circ}[8]$ and by our laboratory. (See Supplemental Materials for tabular $^{\circ}$ listing $^{\circ}$ of $^{\circ}$ the $^{\circ}$ proteins $^{\circ}$ depicted $^{\circ}$ in $^{\circ}$ Figure $^{\circ} 1$, which can be found in the electronic version of this

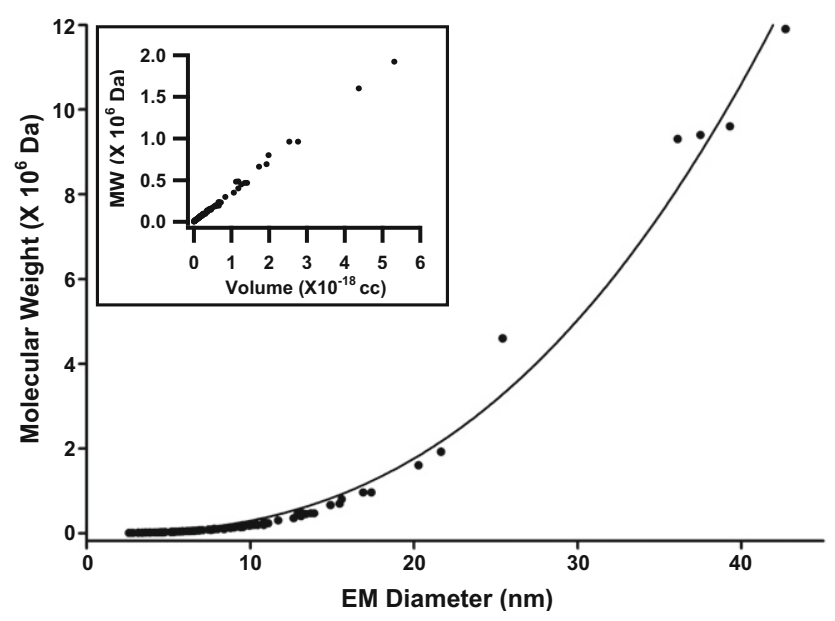

Figure 1. Correlation between electrophoretic mobility measured by ESI-GEMMA and molecular weight for a range of different sized proteins and noncovalent protein complexes. The inset figure shows the linear relationship between the volume of the spherical protein particle calculated from the EMD and the protein molecular weight. article.) Based on the expected relationship between $\mathrm{D}_{\mathrm{EM}}$ and $\mathrm{MW}$ for approximately spherical particles, a power function, $\mathrm{y}=\mathrm{a}_{\mathrm{ox}}{ }^{\alpha 1}$ was chosen for the curve fit analysis. Given eq 4 , it is predicted that $\mathrm{a}_{2}=3$ to describe the trend for MW and $\mathrm{D}_{\mathrm{EM}}$ for approximately spherical particles. The coefficients for the resulting best fit equation are $\mathrm{a}_{0}=750 \pm 140$ and $\mathrm{a}_{1}=2.6 \pm 0.1$.

From eq 4 , the average effective density $(\rho)$ for the protein ${ }^{\circ}$ and ${ }^{\circ}$ protein $^{\circ}$ complexes $^{\circ}$ shown $^{\circ}$ in ${ }^{\circ}$ Figure $^{\circ} 1^{\circ}$ was

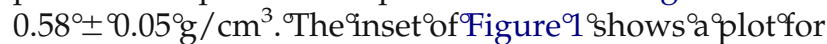
the $\mathrm{MW}$ versus the $\mathrm{V}_{\mathrm{EMD}}$ for the proteins measured by ESI-GEMMA. Given eq 3, the MW per particle was graphed versus $\mathrm{V}_{\mathrm{EMD}}$. For a series of spherical protein particles that display similar compactness, there is a linear relationship between molecular weight and volume $[7,28]$. Thus, ${ }^{9}$ there ${ }^{\circ} s^{\circ} a^{\circ}$ general ${ }^{\circ}$ correlation between the EM diameter and the molecular weight for the proteins and protein complexes studied by our laboratory ${ }^{\circ}$ and ${ }^{\circ}$ that ${ }^{\circ}$ of $^{\circ}$ Bacher $^{\circ}$ et $^{\circ}$ al. $.^{\circ}[8]^{\circ}\left(\right.$ Figure $\left.^{\circ} 1\right) .{ }^{\circ}$ Ranging ${ }^{\circ}$ in molecular weight from $3 \mathrm{kDa}$ to $12 \mathrm{MDa}$, this dataset included monomers and multisubunit complexes, glycopeptides, ribonucleoproteins, globular proteins, and particles of different shapes in solution.

Based on the size range of protein and protein complexes studied by GEMMA measured by our laboratory $^{\circ}$ and $^{\circ}$ by $^{\circ}$ others $^{\circ}\left[3,{ }^{\circ} 29\right],{ }^{\circ}$ the ${ }^{\circ}$ sensitivity ${ }^{\circ}$ of $^{\circ}$ the GEMMA system for studying large protein complexes (i.e., $>500 \mathrm{kDa}$ ) is superior to that of other IMS and MS instruments. On the other hand, the resolving power of GEMMA is relatively low. In previously published reports, the resolution of GEMMA measurements has been compared with that of size exclusion chromatography [10] ${ }^{\circ}$ with the highest observed 'resolving ${ }^{\circ}$ power of $7^{\circ}\left[3,{ }^{\circ} 8-10,{ }^{\circ} 29\right] .{ }^{\circ}$ Based $^{\circ}$ on $^{\circ}$ the $^{\circ} \mathrm{FWHM}^{\circ}$ of ${ }^{\circ}$ the $^{\circ}$ protein standards utilized in these experiments, resolving power of the GEMMA is at best 18 . However, improved resolution may be attained through the use of other DMA models with potential resolving power greater than ${ }^{\circ} 100^{\circ}[9]$.

\section{Protein Complexes Remain Intact Upon Drying, and Charge Reduction and Their Solution-Phase Behavior are Reflected in the Gas Phase}

Using ESI-GEMMA for a number of protein complexes ranging in size between $20 \mathrm{kDa}$ to the mega-Dalton range, ${ }^{\circ}$ the ${ }^{\circ}$ majority ${ }^{\circ}$ of ${ }^{\circ}$ the ${ }^{\circ}$ experimental ${ }^{\circ}$ observations indicate a high degree of correlation in the sizes of the gas-phase protein aggregate/complexes between the gas-phase measurement and the known solutionphase structure. For example, the functional form of enolase from yeast is a dimer of two identical $47 \mathrm{kDa}$ subunits. The X-ray crystallographic structure is shown in $^{\circ}$ Figure $^{\circ} 2$ a. $^{\circ}$ The $^{\circ}$ monomer $^{\circ}$ is $^{\circ}$ egg-shaped ${ }^{\circ}$ with $^{\circ}$ dimensions ${ }^{\circ}$ of $^{\circ} 60^{\circ} \AA^{\circ} \times{ }^{\circ} 55^{\circ} \AA^{\circ} \times{ }^{\circ} 45^{\circ} \AA^{\circ}\left[30,{ }^{\circ} 31\right] .^{\circ}$ Figure ${ }^{\circ} 2 b^{\circ}$ shows the GEMMA spectrum of enolase at $\mathrm{pH}$ 7.4. The primary peak in the spectrum shows an EMD for the enolase dimer at $8.40 \mathrm{~nm}$, with minor contributions for 


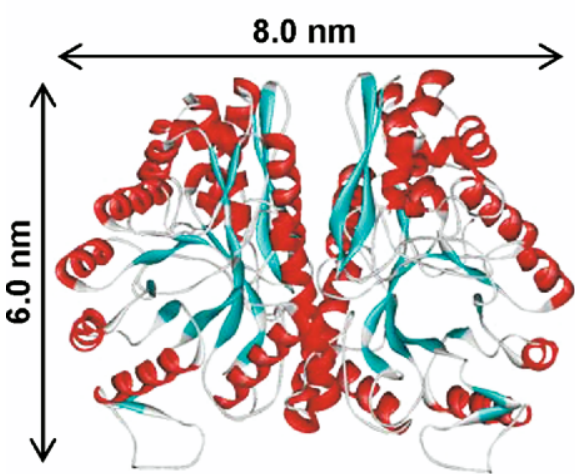

(a)

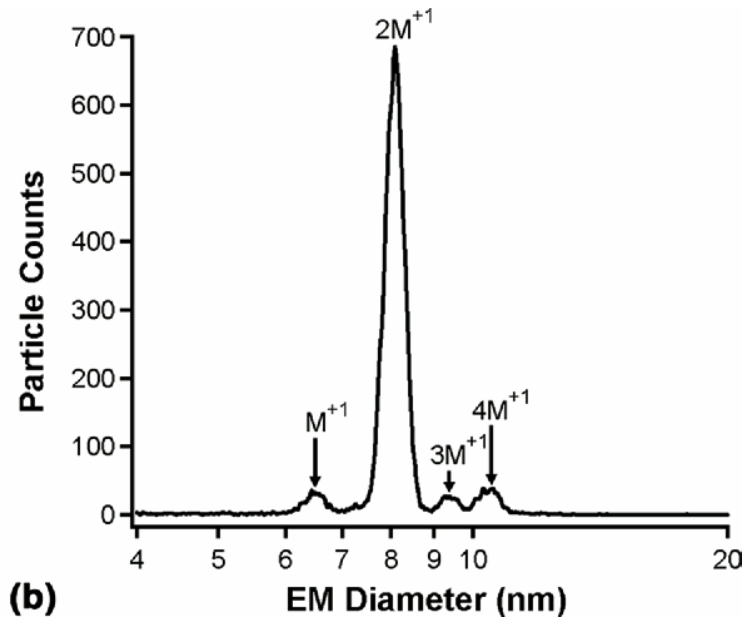

(b)

Figure 2. The 3-D structure of the yeast enolase protein dimer (a) and the ESI-GEMMA spectrum of enolase, showing an EMD consistent for the intact noncovalent dimer complex (b). The structure figure was created using WebLab Viewer with the coordinates from the Protein Data Bank (3ENL).

the monomer $(6.58 \mathrm{~nm})$, trimer $(9.43 \mathrm{~nm})$, and tetramer $(10.45 \mathrm{~nm})$. The ESI (QqTOF) mass spectrum of enolase (Figure $\left.^{\circ} 3\right)^{\circ}$ shows $^{\circ}$ an $^{\circ}$ abundant $^{\circ}$ series $^{\circ}$ of $^{\circ}$ peaks $^{\circ}$ for ${ }^{\circ}$ the multiply charged dimer, in addition to smaller contributions for the monomer and tetramer. At higher $\mathrm{m} / \mathrm{z}$, a low abundant series of peaks for lower charged monomers results from dissociation of the gas-phase protein dimer.

The area of the contact interface between the two subunits ${ }^{\circ}$ is ${ }^{\circ}$ relatively ${ }^{\circ}$ small $^{\circ}(13 \%)^{\circ}[30-32]^{\circ},{ }^{\circ}$ yet $^{\circ}$ the ${ }^{\circ}$ enolase dimer remains intact and is the predominant species in the GEMMA spectrum. The two enolase monomers interact in solution primarily through hydrogen bonding and salt bridges. Compared with hydrophobic interactions, electrostatic interactions are expected to be strengthened in the gas phase upon the removal of water $[33,34] .{ }^{\circ}$ Despite ${ }^{\circ}$ the ${ }^{\circ}$ small ${ }^{\circ}$ area ${ }^{\circ}$ of interaction, ${ }^{\circ}$ the protein dimer remains intact. Because of the charge neutralization ${ }^{\circ}$ process ${ }^{\circ} \mathrm{employed}^{\circ} \mathrm{by}^{\circ} \mathrm{GEMMA}^{\circ}\left[12{ }^{\circ},{ }^{\circ}\right.$ dissociation of the gas-phase singly-charged protein complex is less prevalent than the higher charged molecules measured by ESI-MS.

Larger protein complexes behave similarly upon charge reduction as measured by GEMMA. Ferritins are protein complexes that store and detoxify iron. Eukaryotic apoferritin particles are roughly spherical, hollow protein shells with an o.d. of $12.0 \mathrm{~nm}$ and an i.d. of $8.0^{\circ} \mathrm{nm}^{\circ}[35] .^{\circ}{ }^{\circ} \mathrm{The}^{\circ} \mathrm{Central}^{\circ} \mathrm{Cavity}^{\circ}$ of $^{\circ}$ the ${ }^{\circ}$ ferritin ${ }^{\circ} \mathrm{complex}$ can sequester up to $4500 \mathrm{Fe}$ (III) atoms in the form of a hydrous ferric oxide $\left(5 \mathrm{Fe}_{2} \mathrm{O}_{4} \cdot 3.9 \mathrm{H}_{2} \mathrm{O}\right)$ nanoparticle. As shown ${ }^{\circ}$ by $^{\circ}$ the $^{\circ}$ crystal $^{\circ}$ structure ${ }^{\circ}$ (Figure ${ }^{\circ} 4 \mathrm{~d}$ ), ${ }^{\circ}$ equine spleen ferritin is composed of 24 subunits that individually fold into four helix bundles and which together form a complex displaying octahedral (4-3-2) symmetry [35]. ${ }^{\circ}$ With ${ }^{\circ} a^{\circ}$ monomer ${ }^{\circ}$ molecular ${ }^{\circ}$ weight ${ }^{\circ}$ of $20^{\circ} \mathrm{kDa}$, ${ }^{\circ}$ the molecular weight of the equine spleen apoferritin complex is $\sim 480 \mathrm{kDa}$.

Figure $^{\circ} 4 \mathrm{a}^{\circ}$ shows $^{\circ} \mathrm{a}^{\circ}$ typical $^{\circ} \mathrm{GEMMA}^{\circ}$ spectrum $^{\circ}$ for equine holoferritin. The major peak at $13.2 \mathrm{~nm}$ represents the singly charged 24 subunit ferritin complex. The dimer of the native tetraeicosamer complex $(48 \mathrm{M})$

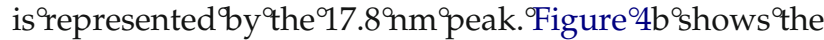
GEMMA spectrum for equine apoferritin. The 24-mer is represented by the major peak at $12.9 \mathrm{~nm}$ and is slightly smaller than that for the holoprotein complex. The dimer of the native apo-tetraeicosamer complex is represented by the $16.9 \mathrm{~nm}$ peak. The spectrum for apoferritin shows also a broad peak indicative of higher order complexes greater than an EMD of $20 \mathrm{~nm}(>1$ $\mathrm{MDa}$ ). This is consistent with that known from solutionphase data, as apoferritin displays a higher ratio of 48-mers and higher order oligomers compared with holoferritin.

There is high structural similarity between the monomers from equine ferritin and archaea Archaeoglobus

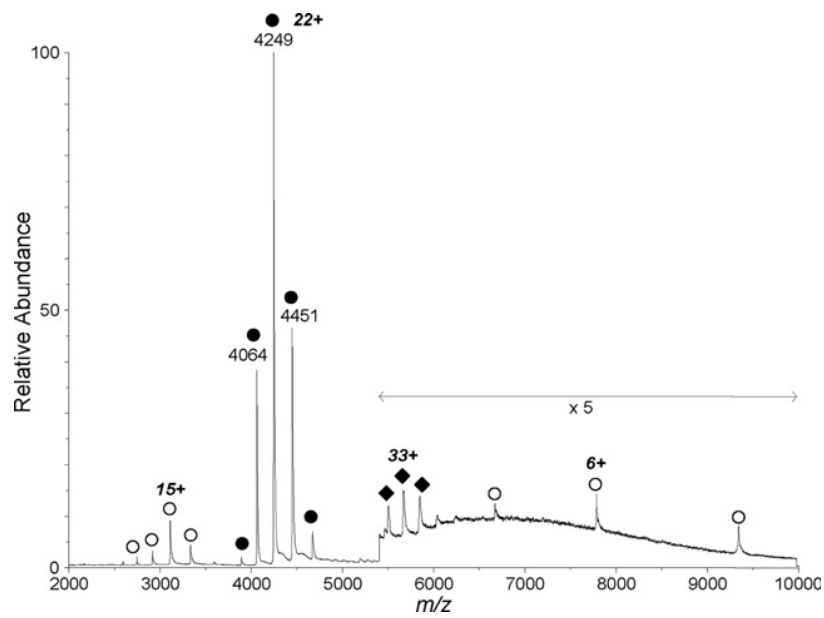

Figure 3. ESI-QqTOF mass spectrum of yeast enolase ( $\mathrm{pH}$ 6.8). The peaks labeled with the open circles, filled circles, and the filled diamonds represent the protein monomer, protein dimer complex, and the protein tetramer, respectively. 


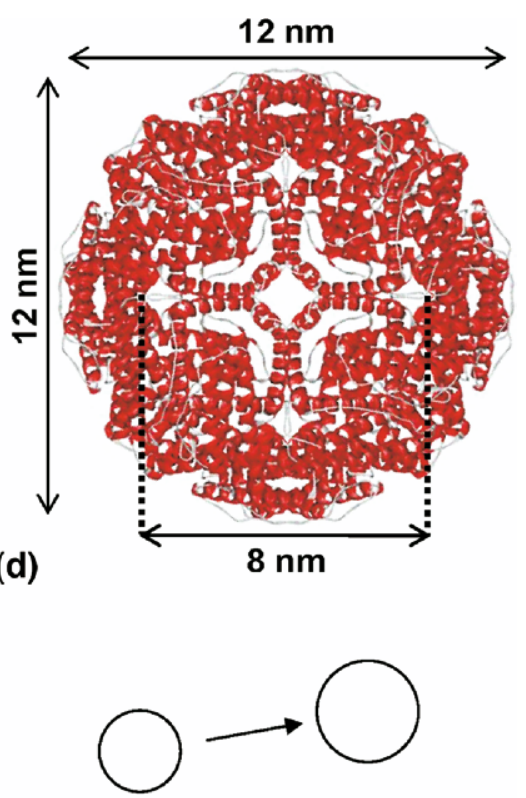

$+$

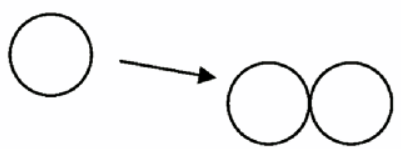

(e)

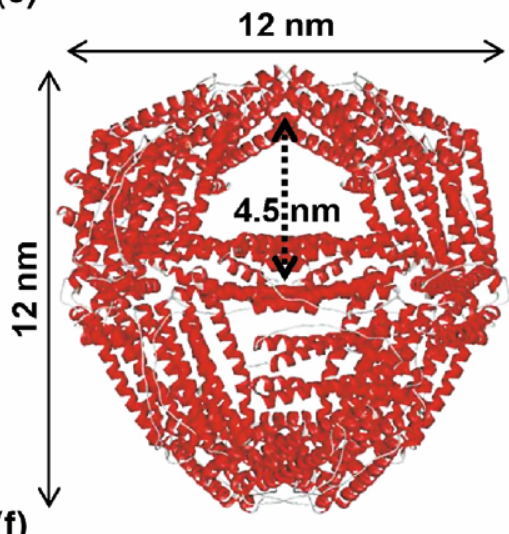

Figure 4. ESI-GEMMA spectra of equine holo-ferritin (a), equine apo-ferritin (b), and apo-ferritin from Archaeoglobus fulgidus (c). The 3-D structures of the 24-mer complexes of equine apo-ferritin and A. fulgidus apo-ferritin are shown in (d) and (f), respectively. The representation of the gas-phase complexation of two 24-mer complexes merging to form the 48-mer dimer complex is shown in (e). Structure figures were created using WebLab Viewer with the coordinates from the Protein Data Bank (1IER, 1S3Q).

fulgidus ferritin ${ }^{\circ}$ Figure $\left.^{\circ} 4 \mathrm{f}\right)^{\circ}[36]^{\circ} .{ }^{\circ}$ Although ${ }^{\circ}$ A. fulgidus is also a tetraeicosameric complex, the quaternary structure is unique among ferritins from prokaryotes and eukaryotes. The A. fulgidus apoferritin displays tetrahedral 2-3 symmetry with four $\sim 4.5 \mathrm{~nm}$ pore openings in its $^{\circ}$ shell ${ }^{\circ}[36] .^{\circ}$ The $^{\circ} \mathrm{EMD}^{\circ}$ of ${ }^{\circ}$ the ${ }^{\circ}$ A. fulgidus apoferritin 24-mer and 48-mer is $13.1 \mathrm{~nm}$ and $17.1 \mathrm{~nm}$, respectively. Reflective of the similar molecular weight of the $A$. fulgidus apoferritin monomer $(20,187 \mathrm{Da})$, the EMD of the tetraeicosamer is in the same size range compared with $^{\circ}$ that $^{\circ}$ of $^{\circ}$ equine ${ }^{\circ}$ apoferritin ${ }^{\circ}$ (Figure ${ }^{\circ} 4$ c) ${ }^{\circ}$ However, reflective of solution behavior in relatively low ionic strength solution, there is a higher concentration of the $40 \mathrm{kDa}$ dimer (2M) in the A. fulgidus apoferritin sample solution ${ }^{\circ}[36] .^{\circ}{ }^{\circ} \mathrm{Th}^{\circ} \mathrm{ESI}^{\circ} \mathrm{mass}^{\circ}$ spectrum $^{\circ}$ shows ${ }^{\circ}$ similarly the relative stability of the $A$. fulgidus apoferritin dimer (Figure 5), ${ }^{\circ}$ although ${ }^{\circ}$ the ${ }^{\circ}$ ultiply ${ }^{\circ}$ charged ${ }^{\circ}$ molecules ${ }^{\circ}$ for the intact $480 \mathrm{kDa} 24-\mathrm{mer}$ are of lower relative abundance compared with the dimer. The particle detection efficiency of the GEMMA instrument increases with 


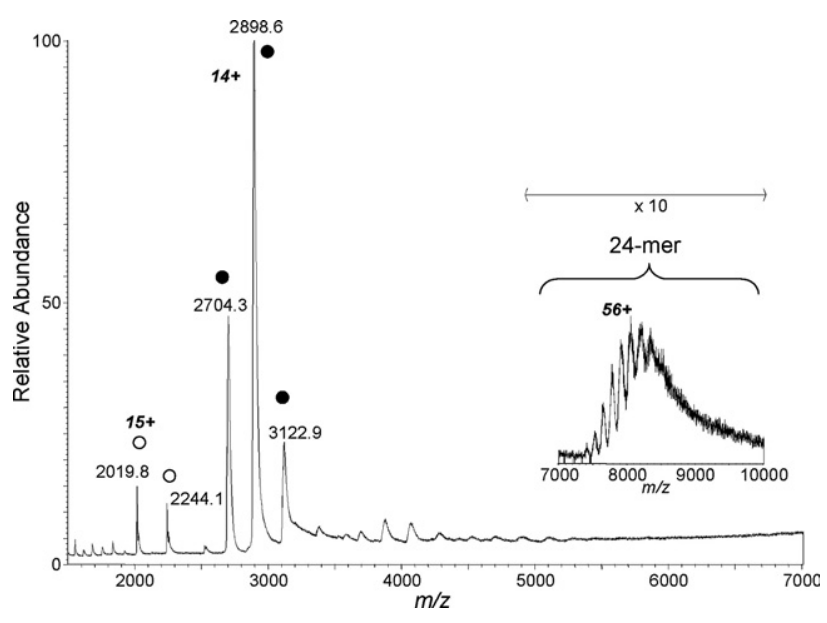

Figure 5. ESI-QqTOF mass spectrum of $A$. fulgidus ferritin. The peaks labeled with the filled circles represent the $2 \mathrm{M}$ ferritin complex, and the higher order intact 24-mer ferritin complex is found at higher $m / z$ (inset).

$\mathrm{EMD}^{\circ}[7] .{ }^{\circ} \mathrm{In}^{\circ}$ addition, ${ }^{\circ}$ likely $^{\circ}$ the $^{\circ}$ multiply $^{\circ}$ charged $^{\circ}$ protein complex molecules are highly susceptible to gasphase fragmentation processes in the mass spectrometer, thus reducing the likelihood for measuring the intact, multiply charged complex by MS compared with their singly charged molecule by GEMMA.

\section{Do Protein Complexes Collapse Upon Introduction to the Gas Phase?}

It is known that structured water plays a role in the folded state of many proteins. Moreover, it has been proposed that evaporation of water in the vicinity of hydrophobic polymer chains such as proteins may provide the driving force for collapse in folding, reflecting ${ }^{\circ}$ the ${ }^{\circ}$ squeezing-out ${ }^{\circ}{ }^{\circ}{ }^{\circ}$ water ${ }^{\circ}$ molecules [37]. Whether gas-phase measurements of large protein assemblies subsequently dehydrated can show evidence for a collapse in protein structure or, more simply, a compaction of protein size, remains a question.

Upon evaporation, hydrophobic interactions would have little meaning in a solventless environment. Within the protein, water molecules reside in the cavities while polar side chains extend into the solvent, maximizing ${ }^{\circ}$ intermolecular ${ }^{\circ}$ interactions ${ }^{\circ}[15] .^{\circ}$ Water molecules bridge hydrogen bonds and can fill the deep clefts and internal cavities of proteins to stabilize native conformation. ${ }^{\circ}$ In ${ }^{\circ}$ the ${ }^{\circ}$ absence ${ }^{\circ}$ of ${ }^{\circ}$ water ${ }^{\circ}$ and ${ }^{\circ}{ }^{\circ}{ }^{\circ} w^{\circ}$ charge, the particle is predicted to collapse such that short range intramolecular interactions such as van der Waals interactions and hydrogen bonds would be the predominant forces dictating the structure of the protein or protein ${ }^{\circ}$ complex [15]. In ${ }^{\circ}$ addition, the $^{\circ}$ volumes ${ }^{\circ}$ of amino acids determined from gas-phase peptides by Clemmer and colleagues are 5 to $20 \%$ smaller than that of protein cores $^{\circ}$ in $^{\circ}$ solution $[38] .{ }^{\circ}$ Thus, ${ }^{\circ}$ although ${ }^{\circ}$ there ${ }^{\circ}$ is $^{\circ}$ evidence to suggest that the anhydrous form of a protein may retain a degree of memory of its solution state, most likely ${ }^{\circ}$ its $^{\circ}$ secondary ${ }^{\circ}$ structure ${ }^{\circ}[39]^{\circ}{ }^{\circ}$ the ${ }^{\circ}$ overall ${ }^{\circ}$ physical dimensions of the gas-phase molecule may be smaller upon dehydration.

For $^{\circ}$ the ${ }^{\circ}$ ferritin $^{\circ}$ protein $^{\circ}$ complexes $^{\circ}\left(\right.$ Figure $\left.^{\circ} 4\right),{ }^{\circ}$ although the diameters based on their crystal structures associated with and without iron are approximately the same $(12.0 \mathrm{~nm})$, the association of the complex with the inner mineral core appears to influence the gas-phase electrophoretic mobility of the molecule. This may demonstrate the ability of the iron core to prevent the ferritin complex from collapsing fully in the gas phase.

As $^{\circ}$ depicted ${ }^{\circ}{ }^{\circ}$ Figure $4 \mathrm{e}$, the ${ }^{\circ}$ gas-phase ${ }^{\circ}$ dimerization of the 24 subunit complex (i.e., 48 -mer) may be represented by the coalescence of two small spheres into a

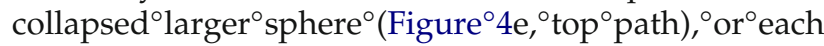
tetraeicosamer may join as two separate small spheres

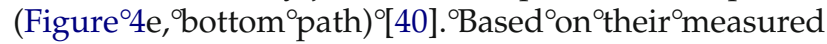
EMDs for the 24-mer and the 48-mer complexes, the ratio of the volume of the 48-mer to the volume of the tetraeicosamer for holo-ferritin (2.45) is larger than 2 and is slightly higher than that of apo-ferritin (2.25). This suggests that the associating tetraeicosamers may retain their structures with the mineral core, preventing complete collapse.

Cowpea ${ }^{\circ}$ Chlorotic mottlevirus, ${ }^{9}(\mathrm{CCMV})^{\circ} 4.6 \mathrm{MDa}$ [41] is a member of the Bromoviridae family bromovirus group of plant viruses. The capsid is composed of $180 \mathrm{chem}-$ ically identical $19.8 \mathrm{kDa}$ subunits (190 amino acids each) arranged with a $\mathrm{T}=3$ icosahedral quasisymmetry. The CCMV quaternary crystal structure displays protruding 32 capsomeres, 12 pentameric, and 20 hexameric morphological ${ }^{\circ}$ units. ${ }^{\circ}$ The ${ }^{\circ}$ whole ${ }^{\circ}$ shell ${ }^{\circ}{ }^{\circ}{ }^{\circ} \mathrm{CCMV}^{\circ}\left(\right.$ Figure $\left.^{\circ} 6 \mathrm{~b}\right)$ has a diameter of $286 \AA$ with a $142 \AA$ maximum radius at the pentamers and a $120 \AA$ minimum radius at the 2 -fold symmetry axes. The average radius of the interior is $142 \AA$ at the pentamers with a minimum radii of $95 \AA$ at $^{\circ}$ the ${ }^{\circ}$ icosahedral $^{\circ} 3$-fold ${ }^{\circ}$ symmetry $^{\circ}$ axes $^{\circ}[42]^{\circ} .^{\circ}$ Four positive sense single-stranded viral RNAs are encapsulated into three morphologically similar virus particles. RNA1 (3171 nucleotides) and RNA2 (2774 nucleotides) are packaged in separate virions. RNA3 (2173 nucleotides) and RNA4 (824 nucleotides) are packaged together ${ }^{\circ}$ into ${ }^{\circ} a^{\circ}$ third ${ }^{\circ}$ virus $^{\circ}$ particle $[43]$.

Consistent with previous work studying viruses using ESI-GEMMA and indicative of a collapsing complex ${ }^{\circ}$ upon ${ }^{\circ}$ desolvation $[13,29]$, the ${ }^{\circ}$ diameters ${ }^{\circ}$ measured are $\sim 10 \%$ less than its X-ray crystal structures dimensions. The EMD of CCMV introduced to the gas phase from $20 \mathrm{mM}$ ammonium acetate was measured to be $25.4^{\circ} \mathrm{nm}^{\circ}$ (Figure $\left.{ }^{\circ} 6 \mathrm{a}\right) .^{\circ}$ Unlike $^{\circ}$ the ${ }^{\circ}$ ferritin ${ }^{\circ}$ examples, ${ }^{\circ}$ the electrophoretic mobility diameter of CCMV is more reflective of the overall physical size of the complex rather than the molecular weight. The effective density $(\rho)$ of $0.89 \mathrm{~g} / \mathrm{cc}$ for the complex is relatively large compared with that of the other protein and protein complexes studied by our laboratory. This may be due to a difference in density between the encapsulated RNA and proteins. RNA may be packed more densely in the gas phase as it does in crystals and in solution. 

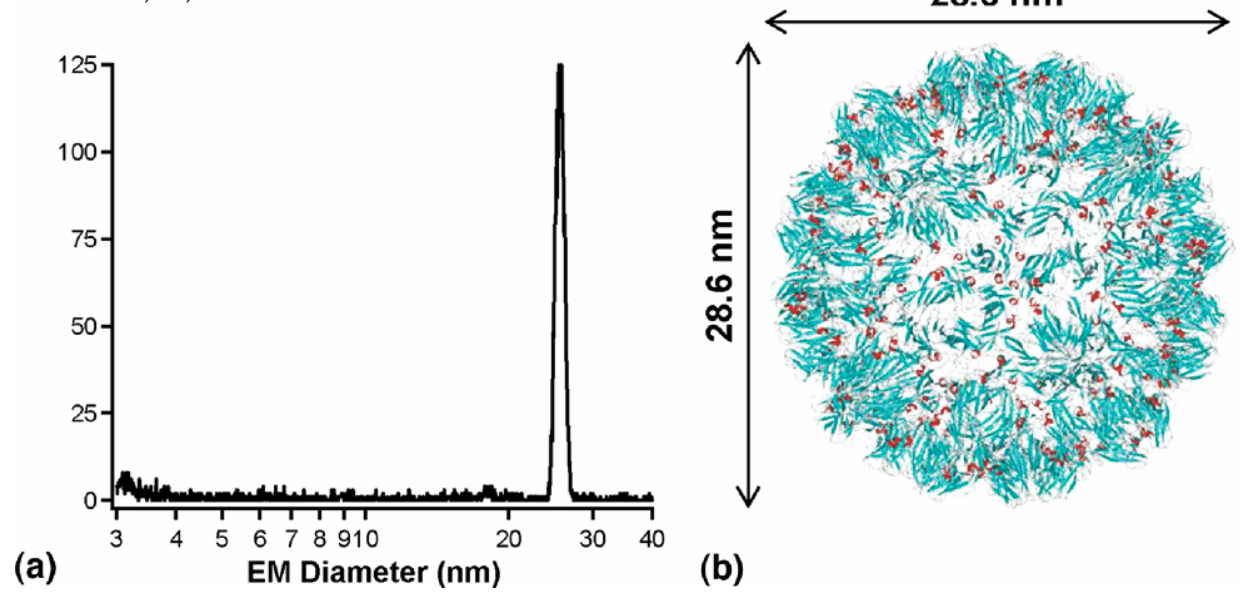

Figure 6. The ESI-GEMMA spectrum of the 4.6 MDa CCMV (cowpea chlorotic mottle virus) complex (a), and its corresponding structure (b) (y-axis is Particle Counts). The structure figure was created using WebLab Viewer with the coordinates from the Protein Data Bank (1CWP).

Based on crystal structure calculations, the partial specific volume of RNA is $0.569 \mathrm{~mL} / \mathrm{g}$, while it is 0.728 $\mathrm{mL} / \mathrm{g}$ for proteins. Based on experimental data, the partial'specific $v o l u m e$ for ${ }^{2} N A 9 s^{9} 0.540 \mathrm{~mL} / \mathrm{g}$ [44]. This is due to the higher number of atoms in an RNA residue versus ${ }^{\circ}$ that ${ }^{\circ}{ }^{\circ}{ }^{\circ} a^{\circ}$ protein $^{\circ}$ residue $[45]$.

\section{Similarly Sized 9 MDa Vault Proteins Can Be Differentiated by Their EMD Measurements}

Vaults are highly conserved ribonucleoprotein particles found in eukaryotes that are proposed to be involved in nuclear cytoplasmic transport. Vaults can be assembled from ${ }^{\circ}$ recombinant ${ }^{\circ} \mathrm{MVP}^{\circ}{ }^{\circ}$ alone ${ }^{\circ}[46]^{\circ}{ }^{\circ}$ Evidence ${ }^{\circ}$ indicates that 48 MVP subunits form the top half of the vault and 48 subunits form the bottom half of the vault, and cryoelectron microscopy (cryo-EM) and single particle reconstruction methods show that the $\mathrm{N}$-termini of the $96^{\circ} \mathrm{MVP}^{\circ}$ subunits ${ }^{\circ}$ meet $^{\circ}$ at $^{\circ}$ the ${ }^{\circ}$ midsection $^{\circ}[47]^{\circ} .{ }^{\circ} \mathrm{In}^{\circ}$ an effort to improve the purification process of the vaults and to learn more about their structure, a series of recombinant MVP variants were designed with various tags on the $\mathrm{N}$-terminus. These included variations of a 12-residue cysteine tag (CP). MVP vaults are particles composed only of a $97 \mathrm{kDa}$ (sequence determined) recombinant major vault protein. Assuming that each of these vault particles is composed of 96 copies of this monomer, the molecular weight of the entire CP-MVP vault complex is proposed to be $9.4 \mathrm{MDa}$. Also, an MVP protein was expressed that had no tag (NT) with the sequence ${ }^{\circ}$ of ${ }^{\circ}$ the ${ }^{\circ}$ rat $^{\circ} \mathrm{MVP} .{ }^{\circ}$ Figure $^{\circ} 7^{\circ}$ and ${ }^{\circ} 8^{\circ}$ show ${ }^{\circ}$ ESIGEMMA spectra of vaults composed of NT-MVP and CP-MVP. The major peak represents the EMD of the singly charged NT-MVP vaults at $36.1 \mathrm{~nm}$ (9.3 MDa) and CP-MVP vaults at $37.5 \mathrm{~nm}(9.4 \mathrm{MDa})$. Half-vaults (ca. 4.6 MDa) and vault aggregates have also been observed $^{\circ}$ by $^{\circ}$ transmission $^{\circ}$ electron ${ }^{\circ}$ microscopy $^{\circ}\left[16,{ }^{\circ} 46\right.$, 47]. ${ }^{\circ}$ Multiply ${ }^{\circ}$ charged $^{\circ}$ vaults $^{\circ}(2+, 3+, 4+)^{\circ}$ were ${ }^{\circ}$ identified by examination of the corresponding mobility values for each of the peaks according to eq 1. The electrophoretic mobility, $Z_{\mathrm{EM}}$, of a multiply charged particle differs from the electrophoretic mobility of the singly charged particle by a factor equal to the charge, $\mathrm{n}$, on the multiply charged particle (i.e., the mobility of $2+, 3+$, and $4+$ charged CP-MVP vaults are, within experimental error, two, three, and four times the mobility of their singly charged counterpart, respectively). This relationship would only be observed if all ions exhibit the same EMD. Thus, it does not appear that the multiply charged MVP vaults represented in Figure ${ }^{\circ} 7^{\circ}$ exist $^{\circ}$ as $^{\circ} a^{\circ}$ more $^{\circ}$ unfolded ${ }^{\circ}$ structure ${ }^{\circ}$ compared with their singly charged counterparts. This is consistent with work from the Jarrold, Clemmer, and Robinson laboratories that protein and protein complexes at relatively low charge states retain their native-like size and $^{\circ}$ structure $\left[4,{ }^{\circ} 14,{ }^{\circ} 15\right] . .^{\circ}$ However, ${ }^{\circ}$ the ${ }^{\circ}$ utility $^{\circ}$ of ${ }^{\circ}$ the DMA for the observation of unfolding induced by Coulomb repulsion has been previously demonstrated by de la Mora and coworkers on much smaller sized $\mathrm{PEG}^{\circ}$ ions ${ }^{\circ}$ at $^{\circ} \mathrm{Charge}^{\circ}$ states $^{\circ} \leq+5^{\circ}[28]$.

Other recombinant MVP variants designed with various tag lengths at the N-terminus include vsvg-MVP 14-residue tag, the His T7 (HT7) 31-residue tag, and the green fluorescent protein (GL) 239-residue tag. As for NT-, CP-MVP vaults, HT7- and GL-MVP vaults were expressed and assembled from the MVP subunit only. Vaults assembled from vsvg-MVP were coexpressed with only TEP1 or TEP1 and VPARP proteins. The GEMMA measurements of this series of recombinant vaults ${ }^{\circ}$ with $^{\circ}$ similar $^{\circ}$ outer $^{\circ}$ dimensions $^{\circ}$ are Iisted $^{\circ}$ in Table 1 , ${ }^{\circ}{ }^{\circ}{ }^{\circ}{ }^{\circ}$ igure ${ }^{\circ}{ }^{\circ}$ shows $^{\circ}$ representative ${ }^{\circ}$ overlaid ${ }^{\circ}$ GEMMA spectra of five variant vault complexes. (The masses of the MVP monomers were determined by MALDI-TOFMS. The expected molecular masses of the MVP-only vaults were determined by multiplying the molecular mass of the MVP monomer by 96, the number of MVP subunits per vault.)

Although the overall physical dimensions are similar, the $9 \mathrm{MDa}$ vault variants can be differentiated by their ${ }^{\circ}$ gas-phase ${ }^{\circ} \mathrm{EMD}^{\circ}\left(\right.$ Figure $\left.^{\circ} 8\right) .^{\circ} \mathrm{As}^{\circ}$ determined ${ }^{\circ}$ by cryo-EM, CP-MVP vaults are $\sim 737 \AA$ long and $410 \AA$ wide [47]. ${ }^{\circ}$ Comparison ${ }^{\circ}$ of $^{9}$ the ${ }^{\circ} \mathrm{MV}$-only ${ }^{\circ}$ vaults ${ }^{\circ}$ shows 

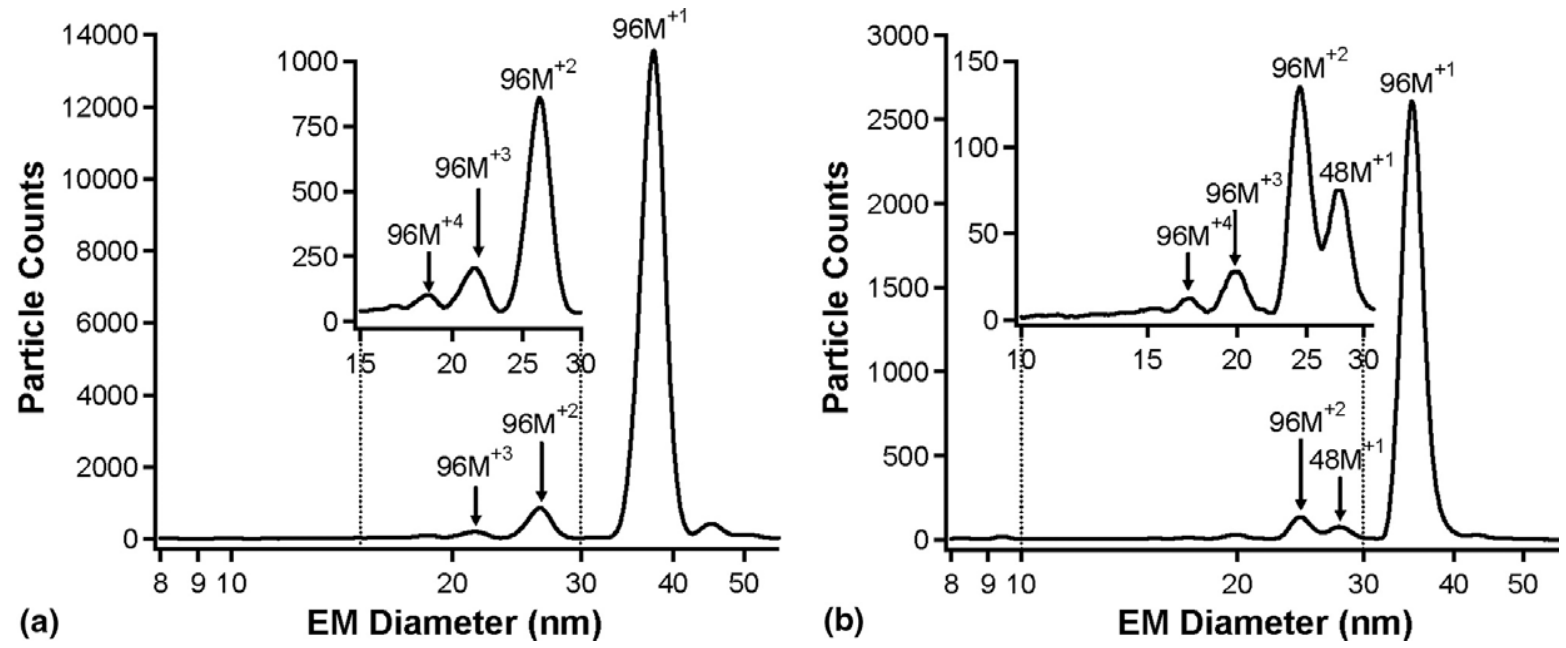

Figure 7. ESI-GEMMA spectra of CP-MVP (a) and NT-MVP (b) vault complexes. Each vault complex is composed of 96 copies of the MVP subunit. Multiply charged molecules of the vaults are indicated in the inset figures.

that an increase in the overall molecular mass of the vaults leads to an increase in the vault EMD. However, likely compression of the vault complexes occurs upon transition to the gas phase, as the measured EMD values range from $36 \mathrm{~nm}$ to $42.7 \mathrm{~nm}$. Removal of water from the protein complexes may result in an overall shrinkage of the complex because the contacts between the protein subunits may shrink. However, this concept will need further validation by examination of a larger number of different-sized protein assemblies.

\section{Conclusions}

There is a general correlation between molecular mass and electrophoretic mobility observed for most protein and protein complexes, ranging in mass from $3 \mathrm{kDa}$ to $12 \mathrm{MDa}$, studied by ESI-GEMMA. Very large protein complexes held together by weak noncovalent forces survive the electrospray and downstream desolvation processes for their subsequent measurement by mass spectrometry and ion mobility. The differences in overall shape and density amongst the mostly globular proteins studied are small in comparison with the resolution of the instrument. However, with increasing numbers of subunits and size, the overall topology and cavity size of protein complexes may vary considerably. These differences in overall shape and density of the complexes can be detected by GEMMA as demonstrated by our studies on ferritin, CCMV, and 9 MDa vaults. Also from this data, we hypothesize that upon desolvation, protein complexes collapse but features of the overall structure are preserved. Future work will address the effect of shape on the measured electrophoretic mobility of large protein assemblies.

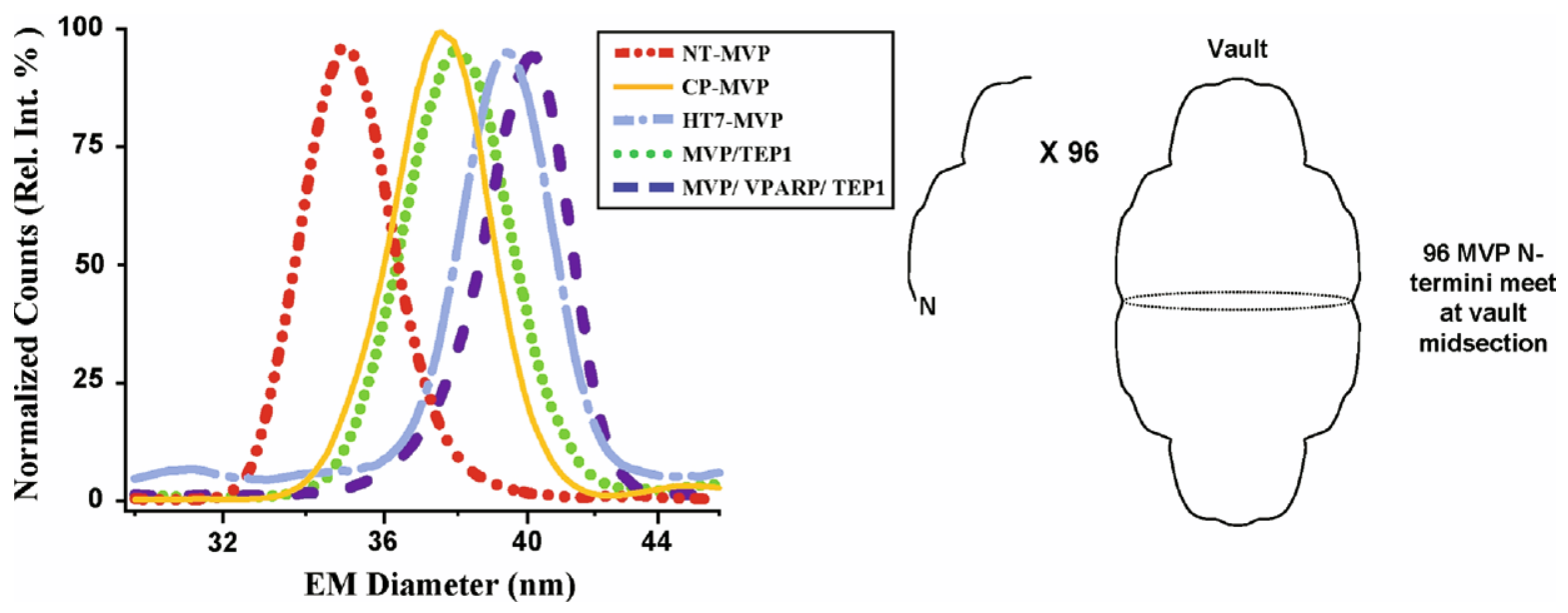

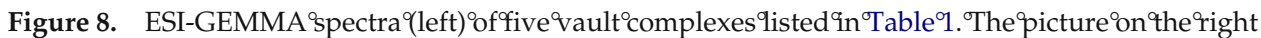
shows the model of how 96 copies of the MVP subunit assemble to form the vault shell; 48 MVP subunits are arranged in each of the top and bottom shells. 
Table 1. Molecular weight and electrophoretic mobility diameters (EMD) of recombinant vaults

\begin{tabular}{|c|c|c|c|c|}
\hline Vault $^{\mathrm{a}}$ & MW of MVP monomer $(\mathrm{kDa})^{\mathrm{b}}$ & MW of vault $(\mathrm{MDa})^{\mathrm{c}}$ & $\operatorname{EMD}(\mathrm{nm})$ & Cryo-EM L X We $(\mathrm{nm} \times \mathrm{nm})$ \\
\hline NT-MVP & 97 & 9.3 & 36.1 & \\
\hline CP-MVP & 98 & 9.4 & 37.5 & $73.7 \times 41.0$ \\
\hline HT7-MVP & 100 & 9.6 & 39.3 & $72.5 \times 41.0$ \\
\hline GL-MVP & 124 & 11.9 & 42.7 & \\
\hline VMVP/VPARP/TEP1 & 99 & $11.8(11.0)^{d}$ & 40.1 & $72.5 \times 41.0$ \\
\hline vMVP/TEP1 & 99 & $10.0(9.6)^{d}$ & 38.0 & $72.5 \times 41.0$ \\
\hline
\end{tabular}

aNT-MVP, CP-MVP, HT7-MVP, MVP/VPARP/TEP1, and MVP/TEP1 are vaults composed of recombinant proteins with peptide tags at the N-terminus. The sequences of the MVP peptide tags are: none (NT-MVP); MAGCGCPCGC GA (CP-MVP); MGSSHHHHHH SSGLVPRGSH MASMTGGQOP W (HT7-MVP); MGYTDIEMNRLGKP (v, vsvg-MVP); MSKGEELFTG VVPILVELDG DVNGHKFSVS GEGEGDATYG KLTLKFICTT GKLPVPWPTL VTTFTYGVOC FSRYPDHMKO HDFFKSAMPE GYVOERTIFF KDDGNYKTRA EVKFEGDTLV NRIELKGIDF KEDGNILGHK LEYNYNSHNV YIMADKOKNG IKVNFKIRHN IEDGSVOLAD HYOONTPIGD GPVLLPDNHY LSTOSALSKD PNEKRDHMVL LEFVTAAGIT HGMDELYKP (GL-MVP). VPARP displays a FLAG tag, MDYKDDDDKV NASR, while TEP1 possesses a double myc sequence, MIANVNIAQE OKLISEEDLA OEQKLISEED LAQOSGGGLD (TEP1). bThe molecular weights of the MVP monomers were determined by MALDI-TOF-MS.

${ }^{\mathrm{C}}$ The molecular weight of the vault complexes composed of recombinant NT-MVP, CP-MVP, or HT7-MVP only were determined by multiplying the molecular weight of the MVP monomer by 96.

${ }^{\mathrm{d}}$ The molecular weight of the vault complexes composed of recombinant proteins MVP/VPARP/TEP1 and MVP/TEP1 were estimated based on eq 4 and an average effective density of $0.58 \mathrm{~g} / \mathrm{cc}$ or from the standard curve shown in Figure 1 (parentheses).

${ }^{\mathrm{e} C}$ Cryo-EM vault dimensions are from reference [47].

\section{Acknowledgments}

The UCLA Functional Proteomics Center was established and equipped by a grant to UCLA from the W. M. Keck Foundation. JAL acknowledges support from the UCLA Jonsson Comprehensive Cancer Center, the U.S. Department of Energy for funding of the UCLA-DOE Institute for Genomics and Proteomics, and the National Institutes of Health (RR 20004). LHR acknowledges support from the National Science Foundation (MCB-0210690) and the G. Harold and Leila Y. Mathers Charitable Foundation (01124244). SHL acknowledges support for a predoctoral fellowship from the NIH Ruth L. Kirschstein National Research Service Award Program (GM075384). Helpful advice on the interpretation of the GEMMA data were provided by Dr. Stanley L. Kaufman (TSI, Inc.), Dr. Guenter Allmaier (Vienna University of Technology, Austria) and his research group, and Dr. Daniel Anderson (UCLA-DOE Institute for Genomics and Proteomics).

\section{References}

1. Bernstein, S. L.; Wyttenbach, T.; Baumketner, A.; Shea, J. E.; Bitan, G.; Teplow, D. B.; Bowers, M. T. Amyloid $\beta$-Protein: Monomer Structure and Early Aggregation States of A $\beta 42$ and Its Pro19 Alloform. J. Am. Chem. Soc. 2005, 127, 2075-2084

2. Koeniger, S. L.; Clemmer, D. E. Resolution and Structural Transitions of Elongated States of Ubiquitin. J. Am. Soc. Mass Spectrom. 2007, 18, 322-331.

3. Loo, J. A.; Berhane, B.; Kaddis, C. S.; Wooding, K. M.; Xie, Y.; Kaufman, S. L.; Chernushevich, I. V. Electrospray Ionization Mass Spectrometry and Ion Mobility Analysis of the 20S Proteasome Complex. J. Am. Soc. Mass Spectrom. 2005, 16, 998-1008.

4. Ruotolo, B. T.; Giles, K.; Campuzano, I.; Sandercock, A. M.; Bateman, R. H.; Robinson, C. V. Evidence for Macromolecular Protein Rings in the Absence of Bulk Water. Science. 2005, 310, 1658-1661.

5. Sharon, M.; Witt, S.; Felderer, K.; Rockel, B.; Baumeister, W.; Robinson, C. V. 20S Proteasomes Have the Potential to Keep Substrates in Store for Continual Degradation. J. Biol. Chem. 2006, 281, 9569-9575.

6. Loo, J. A. Studying Noncovalent Protein Complexes by Electrospray Ionization Mass Spectrometry. Mass Spectrom. Rev. 1997, 16, 1-23.

7. Kaufman, S. L.; Kuchumov, A. R.; Kazakevich, M.; Vinogradov, S. N. Analysis of a 3.6-MDa Hexagonal Bilayer Hemoglobin from Lumbricus terrestris Using a Gas-Phase Electrophoretic Mobility Molecular Analyzer. Anal. Biochem. 1998, 259, 195-202.

8. Bacher, G.; Szymanski, W. W.; Kaufman, S. L.; Zollner, P.; Blaas, D.; Allmaier, G. Charge-Reduced Nano-Electrospray Ionization Combined with Differential Mobility Analysis of Peptides, Proteins, Glycoproteins, Noncovalent Protein Complexes, and Viruses. J. Mass Spectrom. 2001, 36, 1038-1052.

9. de la Mora, J. F.; Ude, S.; Thomson, B. A. The Potential of Differential Mobility Analysis Coupled to MS for the Study of Very Large Singly and Multiply Charged Proteins and Protein Complexes in the Gas Phase. Biotechnol. J. 2006, 1, 988-997.

10. Kaufman, S. L.; Skogen, J. W.; Dorman, F. D.; Zarrin, F.; Lewis, K. C. Macromolecule Analysis Based on Electrophoretic Mobility in Air: Globular Proteins. Anal. Chem. 1996, 68, 1895-1904.
11. Kaufman, S. L. Analysis of Biomolecules Using Electrospray and Nanoparticle Methods: The Gas-Phase Electrophoretic Mobility Molecular Analyzer (GEMMA). J. Aerosol. Sci. 1998, 29, 537-552.

12. Scalf, M.; Westphall, M. S.; Krause, J.; Kaufman, S. L.; Smith, L. M Controlling Charge States of Large Ions. Science. 1999, 283, 194-197.

13. Thomas, J. J.; Bothner, B.; Traina, J.; Benner, W. H.; Siuzdak, G. Electrospray Ion Mobility Spectrometry of Intact Viruses. Spectroscopy. 2004, 18, 31-36.

14. Myung, S.; Badman, E. R.; Lee, Y. J.; Clemmer, D. E. Structural Transitions of Electrosprayed Ubiquitin Ions Stored in an Ion Trap Over $10 \mathrm{~ms}$ to $30 \mathrm{~s}$. J. Phys. Chem. A. 2002, 106, 9976-9982.

15. Shelimov, K. B.; Clemmer, D. E.; Hudgins, R. R.; Jarrold, M. F. Protein Structure in Vacuo: Gas-Phase Conformations of BPTI and Cytochrome c. J. Am. Chem. Soc. 1997, 119, 2240-2248.

16. Kedersha, N. L.; Heuser, J. E.; Chugani, D. C.; Rome, L. H. Vaults. Iii. Vault Ribonucleoprotein Particles Open into Flower-Like Structures with Octagonal Symmetry. J. Cell Biol. 1991, 112, 225-235.

17. Kedersha, N. L.; Miquel, M. C.; Bittner, D.; Rome, L. H. Vaults. II. Ribonucleoprotein Structures Are Highly Conserved among Higher and Lower Eukaryotes. J. Cell Biol. 1990, 110, 895-901.

18. van Zon, A.; Mossink, M. H.; Scheper, R. J.; Sonneveld, P.; Wiemer, E. A The Vault Complex. Cell. Mol. Life Sci. 2003, 60, 1828-1837.

19. Kickhoefer, V. A.; Rajavel, K. S.; Scheffer, G. L.; Dalton, W. S.; Scheper, R. J.; Rome, L. H. Vaults are Up-Regulated in Multidrug-Resistant Cancer Cell Lines. J. Biol. Chem. 1998, 273, 8971-8974.

20. Poderycki, M. J.; Kickhoefer, V. A.; Kaddis, C. S.; Raval-Fernandes, S.; Johansson, E.; Zink, J. I.; Loo, J. A.; Rome, L. H. The Vault Exterior Shell is a Dynamic Structure That Allows Incorporation of Vault-Associated Proteins Into Its Interior. Biochemistry. 2006, 45, 12184-12193.

21. Knutson, E. O.; Whitby, K. T. Aerosol Classification by Electric Mobility: Apparatus, Theory, and Applications. J. Aerosol Sci. 1975, 6, 443-451.

22. Knutson, E. O.; Whitby, K. T. Accurate Measurement of Aerosol Electric Mobility Moments. J. Aerosol Sci. 1975, 6, 453-460.

23. Hinds, W. C. Aerosol Technology: Properties, Behavior, and Measurement of Airborne Particles; John Wiley and Sons, Inc.: New York, N.Y., 1999, pp. $42-72$.

24. Tammet, H. Size and Mobility of Nanometer Particles, Clusters, and Ions. J. Aerosol Sci. 1995, 26, 459-475.

25. Wang, S. C.; Flagan, R. C. Scanning Electrical Mobility Spectrometer. Aerosol Sci. Technol. 1990, 13, 230-240.

26. Fuchs, N. A. On the Stationary Charge Distribution on Aerosol Particles in a Bipolar Ionic Atmosphere. Geofis. Pura. Appl. 1963, 56, 185-193.

27. Wiedensohler, A. An Approximation of the Bipolar Charge Distribution for Particles in the Submicron Size Range. J. Aerosol Sci. 1988, 19, 387-389.

28. Ude, S.; de la Mora, J. F.; Thomson, B. A. Charge-Induced Unfolding of Multiply Charged Polyethylene Glycol Ions. J. Am. Chem. Soc. 2004, 126, 12184-12190.

29. Hogan, C. J.; Kettleson, E. M.; Ramaswami, B.; Chen, D. R.; Biswas, P. Charge Reduced Electrospray Size Spectrometry of Mega- and GigaDalton Complexes: Whole Viruses and Virus Fragments. Anal. Chem. 2006, 78, 844-852.

30. Lebioda, L.; Stec, B.; Brewer, J. M. The Structure of Yeast Enolase at 2.2 -A Resolution. An 8-fold $\beta+\alpha$-Barrel with a Novel $\beta \beta \alpha \alpha(\beta \alpha)_{6}$ Topology. J. Biol. Chem. 1989, 264, 3685-3693.

31. Stec, B.; Lebioda, L. Refined Structure of Yeast Apo-Enolase at $2.25 \AA$ Resolution. J. Mol. Biol. 1990, 211, 235-248.

32. Kornblatt, M. J.; Lange, R.; Balny, C. Use of Hydrostatic Pressure to Produce "Native" Monomers of Yeast Enolase. Eur. J. Biochem. 2004, 271, 3897-3904. 
33. Loo, J. A. Electrospray Ionization Mass Spectrometry: A Technology for Studying Noncovalent Macromolecular Complexes. Int. J. Mass Spectrom. 2000, 200, 175-186.

34. Xie, Y.; Zhang, J.; Yin, S.; Loo, J. A. Top-Down ESI-ECD-FT-ICR Mass Spectrometry Localizes Noncovalent Protein-Ligand Binding Sites. J. Am. Chem. Soc. 2006, 128, 14432-14433.

35. Granier, T.; Gallois, B.; Dautant, A.; Langlois d'Estaintot, B.; Precigoux, G. Comparison of the Structures of the Cubic and Tetragonal Forms of Horse-Spleen Apoferritin. Acta Cryst. 1997, D53, 580-587.

36. Johnson, E.; Cascio, D.; Sawaya, M. R.; Gingery, M.; Schroder, I Crystal Structures of a Tetrahedral Open Pore Ferritin from the Hyperthermophilic Archaeon. Archaeoglobus fulgidus. Structure. 2005, 13, 637-648.

37. Rhee, Y. M.; Sorin, E. J.; Jayachandran, G.; Lindahl, E.; Pande, V. S. Simulations of the Role of Water in the Protein-Folding Mechanism. Proc. Natl. Acad. Sci. U.S.A. 2004, 101, 6456-6461.

38. Counterman, A. E.; Clemmer, D. E. Volumes of Individual Amino Acid Residues in Gas-Phase Peptide Ions. J. Am. Chem. Soc. 1999, 121, 4031-4039.

39. Koeniger, S. L.; Merenbloom, S. I.; Sevugarajan, S.; Clemmer, D. E. Transfer of Structural Elements from Compact to Extended States in Unsolvated Ubiquitin. J. Am. Chem. Soc. 2006, 128, 11713-11719.

40. Petsev, D. N.; Thomas, B. R.; Yau, S.; Vekilov, P. G. Interactions and Aggregation of Apoferritin Molecules in Solution: Effects of Added Electrolytes. Biophys. J. 2000, 78, 2060-2069.
41. Bancroft, J. B.; Hiebert, E.; Rees, M. W.; Markham, R. Properties of Cowpea Chlorotic Mottle Virus, Its Protein, and Nucleic Acid. Virology. 1968, 34, 224-239.

42. Speir, J. A.; Munshi, S.; Wang, G.; Baker, T. S.; Johnson, J. E. Structures of the Native and Swollen Forms of Cowpea Chlorotic Mottle Virus Determined by X-Ray Crystallography and Cryo-Electron Microscopy. Structure. 1995, 3, 63-78.

43. Dasgupta, R.; Kaesberg, P. Complete Nucleotide Sequences of the Coat Protein Messenger RNAs of Brome Mosaic Virus and Cowpea Chlorotic Mottle Virus. Nucleic Acids Res. 1982, 10, 703-713.

44. Durchschlag, H. Specific Volumes of Biological Macromolecules and Some Other Molecules of Biological Interest. In Thermodynamic Data for Biochemistry and Biotechnology; Hinz, H.-J., Ed.; Springer Verlag: Berlin, 1986; pp 45-128.

45. Voss, N. R.; Gerstein, M. Calculation of Standard Atomic Volumes for RNA and Comparison with Proteins: RNA is Packed More Tightly. J. Mol. Biol. 2005, 346, 477-492.

46. Stephen, A. G.; Raval-Fernandes, S.; Huynh, T.; Torres, M.; Kickhoefer, V. A.; Rome, L. H. Assembly of Vault-Like Particles in Insect Cells Expressing Only the Major Vault Protein. J. Biol. Chem. 2001, 276, 23217-23220

47. Mikyas, Y.; Makabi, M.; Raval-Fernandes, S.; Harrington, L.; Kickhoefer, V. A.; Rome, L. H.; Stewart, P. L. Cryoelectron Microscopy Imaging of Recombinant and Tissue Derived Vaults: Localization of the MVP N-Termini and VPARP. J. Mol. Biol. 2004, 344, 91-105. 